\title{
空カタブのノズル形状ならびに間欠噴射が 超音速噴流騒音に及ぼす効果*1 \\ Effects of Nozzle Geometry and Intermittent Injection of Aerodynamic Tab on Supersonic Jet Noise
}

\author{
荒木幹 也*2 ·佐野貴 透*3 - 福田将 之*3 - 小島孝 之*4 \\ Mikiya Araki, Takayuki Sano, Masayuki Fukuda, Takayuki KoJIMA, \\ 田口秀 之*5 ·志賀 聖 一*2 · 小保方 富 夫*2 \\ Hideyuki Taguchi, Seiichi Shiga and Tomio Obokata
}

Key Words : Jet Noise, Aerodynamic Tab, Plug Nozzle, Wedge Nozzle, Intermittent Injection

\begin{abstract}
Effects of the nozzle geometry and intermittent injection of aerodynamic tabs on exhaust noise from a rectangular plug nozzle were investigated experimentally. In JAXA (Japan Aerospace Exploration Agency), a pre-cooled turbojet engine for an HST (Hypersonic transport) is planned. A 1/100-scaled model of the rectangular plug nozzle is manufactured, and the noise reduction performance of aerodynamic tabs, which is small air jet injection from the nozzle wall, was investigated. Compressed air is injected through the rectangular plug nozzle into the atmosphere at the nozzle pressure ratio of 2.7, which corresponds to the take-off condition of the vehicle. Aerodynamic tabs were installed at the sidewall ends, and 4 kinds of round nozzles and 2 kinds of wedge nozzles were applied. Using a high-frequency solenoid valve, intermittent gas injection is also applied. It is shown that, by use of wedge nozzles, the aerodynamic tab mass flow rate, necessary to gain $2.3 \mathrm{~dB}$ reduction in OASPL (Overall sound pressure level), decreases by $29 \%$ when compared with round nozzles. It is also shown that, by use of intermittent injection, the aerodynamic tab mass flow rate, necessary to gain $2.3 \mathrm{~dB}$ reduction in OASPL, decreases by about $40 \%$ when compared with steady injection. By combination of wedge nozzles and intermittent injection, the aerodynamic tab mass flow rate significantly decreases by $57 \%$ when compared with the conventional strategy.
\end{abstract}

\section{1. 緒言}

拡大する世界の航空需要を満たすため, 航空機の高速化 は必須の課題である。これに伴い世界各国で次世代の超音 速旅客機の開発が進められている. 第 1 困に, 宇宙航空研 究開発機構 (JAXA) で計画中の予冷ターボジェットエン ジン1) 概略を示す。これはHST (Hypersonic transport) エンジンとして計画されているもので, マッハ 0 からマッ 八 5 の極超音速飛行までの加速を行う. 従来の航空機と同 様に空港から水平離陸する計画となっており, 離陸時の工 ンジン騷音低減が必須の課題となっている。

著者らはこれまで, 軸対称不足膨張噴流からの噴流騒音 低減に関する研究を行ってきた ${ }^{2 \sim 4}$. 不足膨張噴流から放 出されるスクリーチおよびブロードバンドノイズを, ノズ ル壁面からの少量の気体噴射で低減するというものである. 従来の機械式タブと同様の効果を流体力学的に得るもので,

\footnotetext{
*1 C) 2008 日本航空宇宙学会

平成 20 年 8 月 13 日原稿受理

*2 群馬大学大学院工学研究科機械システム工学専攻

*3 群馬大学大学院工学研究科機械システム工学専攻修士課程

*4 宇宙航空研究開発機構総合技術研究本部

*5 宇宙航空研究開発機構航空プログラムグループ
}

著者らは空力タブ (AT: Aerodynamic tab) と称している. また著者らは，この空力夕ブを JAXA で計画中の予冷ター ボジェットエンジン排気ノズル (矩形プラグノズル) 1) に適 用し, 噴流騒音低減効果ならびにメカニズムの検証を行っ てきた5)。

空力タブの利点として，(i) 高温・高速排気に機械部品が さらされることがないため信頼性が向上すること, (ii) 飛 行条件に応じて空力タブの噴射位置・条件を容易に变更で きること，（iii）洋上飛行など騷音が問題とならない飛行条 件では, 空力タブを停止することで推力損失から逃れられ ることなどがあげられる。信頼性・制御性の観点から有望 な騒音低減法といえる。また近年ターボファンエンジンへ の適用が進んでいるシェブロンノズル $(2 \sim 3 \mathrm{~dB}$ の騒音低 減効果が認められている）と同様に，エンジン構造の根本 的な設計変更を最小限にとどめることができるため, 既存 エンジンへの搭載が比較的容易であるという利点も有する. しかしながら, 一定の騒音低減効果を得るためにはかなり の流量の空気を空力タブから噴出する必要があることも明 らかになっている5 . 矩形プラグノズル ${ }^{1)}$ の場合, 噴流騒音 の全音圧レベル（OASPL: Overall sound pressure level） を $2.4 \mathrm{~dB}$ 低減することに成功したものの，これには主噴流 


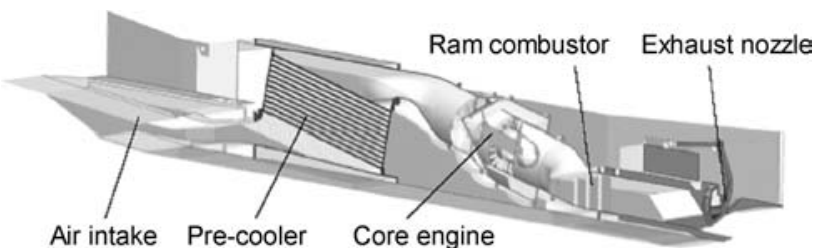

第 1 図 予冷ターボジェットエンジン1) 概略

の約 $4 \mathrm{wt} \%$ の空気を空力タブから噴出する必要があること が示されている5). なお, $2 \sim 3 \mathrm{~dB}$ の騒音低減で予冷夕ーボ ジェットエンジンの騒音問題がすべて解決するわけではな い. しかしながら，既存のエンジンの性能を大きく損なう ことなく, 騒音を低減できることのメリットは大きいと考 えている.

予冷ターボジェットエンジン1)への適用を考えた場合, 空 カタブの圧力源には，コアエンジンのコンプレッサ抽気が 想定されている. $4 \mathrm{wt} \%$ の抽気はそのまま $4 \%$ の推力低下に つながるため，容認できない量である，通常ジェットエン ジンでは, キャビン与圧ならびにタービン翼・軸受冷却の ため 1〜2wt\%の抽気が行われる. 著者らは, 少なくともこ れと同程度まで空力タブの流量を低減する必要があると考 えている.

本研究では, 騒音問題が深刻な離陸時条件に着目し, 空 カタブの効果的な噴射条件を検討する. 特に, (i) 空力タブ のノズル形状変更，(ii）空力タブからの間欠気体噴射適用 を行うことで, これまでと同程度の騒音低減効果 $(2 \sim 3 \mathrm{~dB}$ 減）を維持しつつ, 気体流量の大幅な低減を目論む. 超音 速主流に対し空力タブからの噴流を効果的に貫通させるた め, スクラムジェット燃焼器などで用いられるくさび形ノズ ル6) を適用する。また高速電磁弁を用い, 空力タブからの 気体噴射を断続的に休止する間欠噴射を行い, その流量低 減を試みる。本研究では, 矩形プラグノズル11)からの噴流 騒音の OASPL が最大となる位置 ${ }^{5)}$ に高周波マイクロフォ ンを設置し, 空力タブの騒音低減効果を検討する。ノズル 周りの 1 点での計測であるものの, 前報5)の計測結果から, 矩形プラグノズルからの噴流騒音を代表するデータである と考えている.

\section{2. 実験装置および方法}

2.1 矩形プラグノズル 第 2 図に, 矩形プラグノズル 概略を示す。現在 JAXA で計画中の予冷ターボジェットエ ンジン1) 排気ノズルの, 約 $1 / 100$ サイズの縮小模型を製作 し実験に供した。前報5) と重複する部分もあるが，前報と は供試ノズルの外形状が異なっているため詳細に説明する.

スクリューコンプレッサからの高圧空気は, 配管を通っ て実験室に導かれる。高圧空気は, 矩形プラグノズルから 噴出する超音速噴流 (以下, 主噴流) 用ライン, および空 カタブ用ラインに分流される。主噴流用ラインに導かれた 空気は，レギュレータにより設定圧力に調圧された後，八 ニカム, ストレーナからなる整流室を経て矩形プラグノズ ルに導かれる。

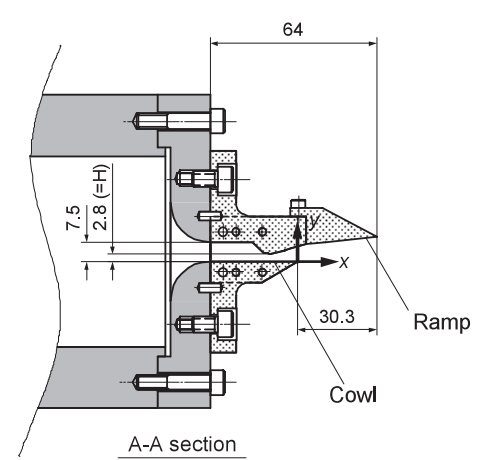

(a) 側面図

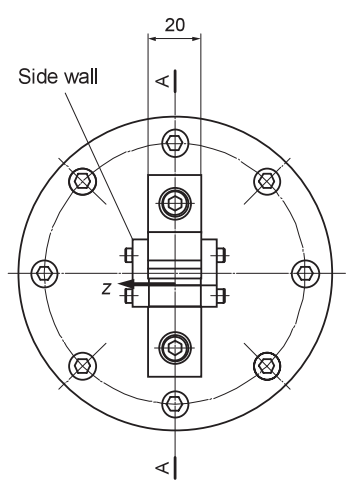

(b) 正面図
第 2 図 矩形プラグノズル概略

第 1 表 主噴流の温度 · 圧力条件

\begin{tabular}{ll}
\hline Nozzle inlet total press. & $0.27 \mathrm{MPa}(\mathrm{a})$ \\
Nozzle exit static press. & $0.10 \mathrm{MPa}(\mathrm{a})$ \\
Nozzle press. ratio & 2.7 \\
Total temp. & $288 \mathrm{~K}$ \\
Working gas & Air \\
\hline
\end{tabular}

矩形プラグノズル縮小模型は，ランプ，カウル，側壁か らなる。ノズルスロート上流からランプ下流端までが再現 されている。ノズルスロート上流の流路はストレートで, 幅 $20 \mathrm{~mm}$, 高さ $7.5 \mathrm{~mm}$ である. 実機のノズルスロートは 面積可変機構を有しているが, 本研究では, 簡単のためそ の面積を固定とした。ノズルスロートは離陸時条件の形状 (スロート全開) となっており，その寸法は，幅 $20 \mathrm{~mm}$, 高 さ $2.8 \mathrm{~mm}$ である.ノズルスロート高さを $H$ とおく.

流路下壁は, 実機のカウルに対応する，実機のカウルは軽 量化のため面積可変機構を有しておらず，その出口までス トレートの固定形状である. カウル出口寸法は, 幅 $20 \mathrm{~mm}$, 高さ $5.9 \mathrm{~mm}$ である. カウル出口を通過した空気はランプ に沿って流れ，ランプ下流端から大気へと噴出する。側壁 下流端は, 実機では鋭角のエッジとなっている。本研究で は，ここに空力タブノズルを設置するため，鋭角ではなく 直角のエッジとなっている。座標系は, カウル下流端中央 を原点とし, 流れ方向に $x$ 軸, 鉛直上向きに $y$ 軸, スパ ン方向に $z$ 軸とする.

矩形プラグノズルから噴出する主噴流の, 流れ場特性（速 度分布, 衝撃波等の圧力波形成, 渦形成) の詳細, ならび に騒音特性（ノズル周り OASPL 分布）の詳細については, 前報5)を参照されたい.

第 1 表に, 主噴流の温度 ·圧力条件を示す.ノズル入口 全圧は $0.27 \mathrm{MPa}(\mathrm{a})$, ノズル出口静圧は大気圧である。ノ ズル圧力比は 2.7 であり, 実機1) の離陸時条件に対応する. 空力夕ブを用いた場合，その閉塞効果によって実質的なノ ズル出口面積が減少する. 本研究では, 空力タブを用いた 場合でも，常にノズル入口全圧を $0.27 \mathrm{MPa}(\mathrm{a})$ に保って実 験を行った。 空気加熱を行っていないため, 全温は室温で ある。また作動流体は，燃焼ガスではなく空気である。こ れらから, 排気速度は実機と一致しない. カウル出口およ びランプ下流端における流速（ピトー管による実測值）は， 
それぞれ $362 \mathrm{~m} / \mathrm{s}, 340 \mathrm{~m} / \mathrm{s}$ である5).

2.2 空カタブ 第 3 図に, 空力タブ設置位置概略を示 す. 前報5) では, ランプ下流端, カウル下流端, 側壁下流端 の 3 カ所に空力タブを設置し, 騷音低減効果の検討を行っ た.この結果, 空力タブを側壁下流端に設置した場合に騒音 低減効果が最も大きいことが示されている5). 本研究では, 空力タブは側壁下流端にのみ設置される. 空力夕ブは左右 の側壁内部に 1 本ずつ埋め込まれ，左右同時に噴射される. ノズル位置は，側壁下流端から $2 \mathrm{~mm}$ 上流の位置である。

第 2 表に, 空力タブの温度・圧力条件を示す. 空力夕ブ用 ラインに導かれた空気は, レギュレータにより設定圧力に 調圧された後，フレキチューブを経て空力タブノズルに導か れ, 主噴流に対して噴出する. 空力タブ全圧を $0.10 \mathrm{MPa}(\mathrm{a})$ (噴射なし) 〜 $0.60 \mathrm{MPa}(\mathrm{a})$ の範囲で変化させた. 空気加熱 を行っていないため, 全温は室温である. 空力タブ全圧の 上限值は, 実機1) の離陸時のコンプレッサ抽気圧力（コア エンジンのコンプレッサ圧力比 $=6)$ をもとに設定した.

第 4 図に, 空力タブのノズル形状概略を示す. 前報5)で は, ノズル出口直径 $d=0.8 \mathrm{~mm}$ の円形先細ノズルのみを 用いた. 本研究では, 空力タブのノズル形状が騒音低減性

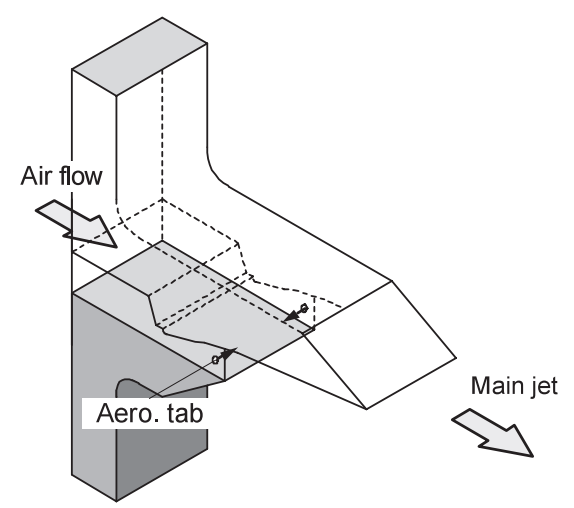

\section{第 3 図 空力タブの設置位置概略}

第 2 表 空力タブの温度 · 圧力条件

\begin{tabular}{ll}
\hline Total press. & 0.10 (No injection) to $0.60 \mathrm{MPa}(\mathrm{a})$ \\
Total temp. & $288 \mathrm{~K}$ \\
Working gas & Air \\
\hline
\end{tabular}

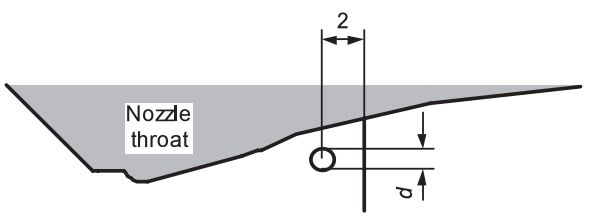

(a) 円形先細ノズル（Round AT）

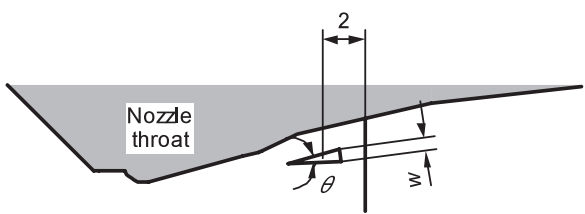

(b)くさび形先細ノズル（Wedge AT）

第 4 図 空力タブのノズル形状概略
能に及ぼす影響を調査するため, 直径 $d$ の異なる円形先細 ノズル (Round AT), ならびに全角 $\theta$ の異なるくさび形 先細ノズル（Wedge AT）を用いた. 前報5) の可視化実験 より，主噴流はノズルスロートで転向し，ランプに沿って 流れることが確認されている. くさび形ノズル設置の際に は，〈さび形が主噴流に正対するように角度を調整した。

第 3 表に, 空力タブのノズル形状条件を示す. 4 種類の 円形先細ノズル (ノズル出口直径 $d=0.3 \sim 1.0 \mathrm{~mm}$ ), な らびに 2 種類のくさび形先細ノズル（くさび全角 $\theta=14$ $27 \mathrm{deg})$ を用いた。ノズルスロート高さ $H(=2.8 \mathrm{~mm})$ を基準とすると, その閉塞高さは, 円形ノズルの場合 0.1 $<d / H<0.4$ 程度, 〈さび形ノズルの場合 $w / H=0.2$ 程 度である。また，〈さび形ノズルの出口面積は， $d=0.7$ $0.8 \mathrm{~mm}$ の円形ノズルに対応する。

第 5 図に, 空力タブの間欠噴射法概略を示す. 前報5)で は, 空力タブは定常噴射であった. 本研究では, 空力タブか らの気体噴射を断続的に休止する間欠噴射を適用すること

第 3 表 空力タブのノズル形状条件

\begin{tabular}{ll}
\hline $\begin{array}{l}\text { No injection } \\
(\mathrm{W} / \mathrm{O} \text { AT })\end{array}$ & - \\
\hline Converging & Nozzle diam. $d=0.3 \mathrm{~mm}(d / H=0.11)$ \\
round nozzle & Nozzle diam. $d=0.5 \mathrm{~mm}(d / H=0.18)$ \\
(Round AT) & Nozzle diam. $d=0.8 \mathrm{~mm}(d / H=0.29)$ \\
& Nozzle diam. $d=1.0 \mathrm{~mm}(d / H=0.36)$ \\
\hline Converging & Wedge full angle $\theta=14 \mathrm{deg}(w / H=0.19)$ \\
wedge nozzle & Wedge full angle $\theta=27 \mathrm{deg}(w / H=0.23)$ \\
$($ Wedge AT) & \\
\hline
\end{tabular}

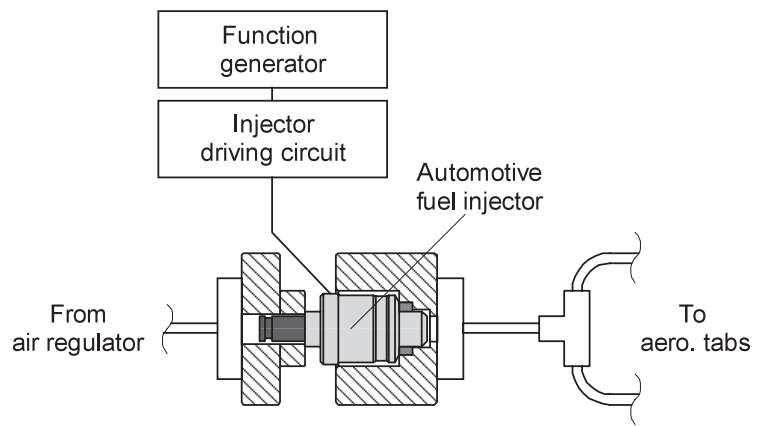

(a) 空力タブの間欠噴射装置概略
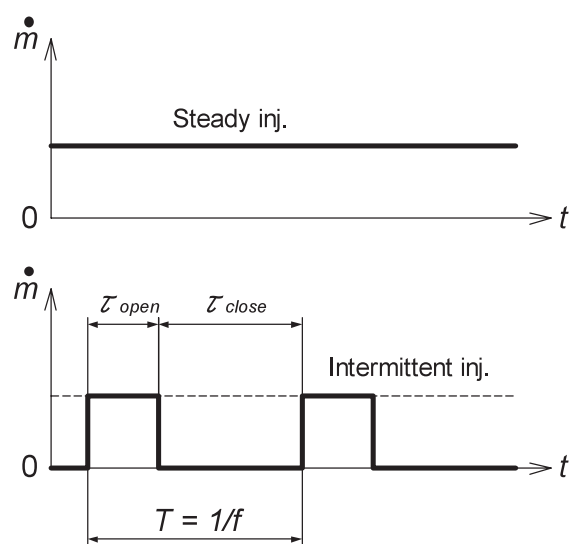

(b) 空力タブの気体流量履歴

第 5 図 空力タブの間欠噴射法概略 
で，その流量低減を試みる. $100 \mathrm{~Hz}$ オーダでの高速作動が 可能な電磁弁として, 天然ガス自動車用燃料噴射弁（ケー ヒン社，06164 PDN J007) を用いた。自動車用燃料噴射 弁は，典型的な高速電磁弁である。 $1 \mathrm{~ms}$ 以内で開弁動作・ 閉弁動作が完了し，全開状態・全閉状態を任意の期間保持 することができる7).

第 5 図 (a)に, 空力夕ブの間欠噴射装置概略を示す. 自動 車用燃料噴射弁は空力タブ配管中に設置される. 自動車用 燃料噴射弁を通過した空気は 2 本に分流され, 左右の側壁 に設置された空力タブへと導かれる。左右の配管は等長で あり, 左右の空力タブからは同位相で気体が噴出する. 自 動車用燃料噴射弁は，ファンクションジェネレータで発生 される方形波信号で開弁・閉弁駆動される. なお, 自動車 用燃料噴射弁の流量は十分大きく7), 圧力損失は無視でき ることが確認されている.

第 5 図 (b) に, 空力タブの気体流量履歴を示す. 自動車 用燃料噴射弁を周期的に開弁 ·閉弁する。燃料噴射弁の開 弁・閉弁動作は $1 \mathrm{~ms}$ 以内に完了するため, 質量流量は第 5 図 (b) に示すような方形波に近い履歴となる7). 開弁・閉 弁動作の周波数を，噴射周波数 $f$ とおく. 噴射 1 周期のう ち，噴射弁の開弁期間を $\tau_{\text {open, }}$ 閉弁期間を $\tau_{\text {close }}$ とおく. また噴射 1 周期のうち，噴射弁が開弁している期間の割合 を, 噴射デューティー比 $D R$ とし, 次式で定義する.

$$
D R=\frac{\tau_{\text {open }}}{\tau_{\text {open }}+\tau_{\text {close }}}
$$

第 4 表に, 空力タブの間欠噴射条件を示す. 本研究では, 定常噴射および 3 種類の周波数での間欠噴射（噴射周波数 $f=10 \sim 100 \mathrm{~Hz}$ ) を行った. また噴射デューティー比 $D R$ を変化させた $(0.3<D R<0.8)$. 間欠噴射を行う場合に は, 空力タブ全圧を $0.6 \mathrm{MPa}(\mathrm{a})$ で固定とした。この場合, 空力夕ブの時間平均流量は, 噴射デューティー比 $D R$ に比 例する. なお，噴射周波数 $f=100 \mathrm{~Hz}$ の条件では，噴射 デューティー比を 0.5 より小さくすると開弁期間が過小と なり噴射弁が正常に作動しないため, 条件から省いてある.

空力タブ噴射周波数は最大でも $100 \mathrm{~Hz}$ のオーダであり, 主噴流騒音のピーク周波数 $(10 \mathrm{kHz}$ のオーダ $)$ と比較して かなり小さい.これは, 自動車用燃料噴射弁の作動周波数 の限界によるためである。本研究で行った間欠噴射は, 主 噴流の流れの不安定性を励起するというより，単純に噴射 休止することで流量低減を図ったものであると考えている.

2.3 計測法 マイクロフォン (Bruel \& Kjaer 社, 4939) を用い，騒音計測を行った．マイクロフォンは直径 $6 \mathrm{~mm}$ の支持棒先端に取り付けられ，測定位置まで挿入される。マ

第 4 表 空力タブの間欠噴射条件

\begin{tabular}{cll}
\hline Steady injection & - & - \\
\hline Intermittent & Injection freq. & Injection duty ratio \\
injection & $f=10 \mathrm{~Hz}$ & $D R=0.3,0.5,0.8$ \\
& $f=50 \mathrm{~Hz}$ & $D R=0.3,0.5,0.8$ \\
& $f=100 \mathrm{~Hz}$ & $D R=0.5,0.8$ \\
\hline
\end{tabular}

For intermittent injection cases, AT total pressure is kept at $0.6 \mathrm{MPa}(\mathrm{a})$.
イクロフォンは送り装置に固定されており，任意の位置で の計測が可能であるが, 本研究では OASPL が最大となる ランプ下流側の参照点 $(x=130 \mathrm{~mm}, y=120 \mathrm{~mm}, z=$ $0 \mathrm{~mm})^{5)}$ でのみ計測を行った. マイクロフォンは, そのセン サ面が $x$ 軸に平行になるように設置される。ママイクロフォ ンからの電圧信号は, デジタルオシロスコープ (LeCroy 社, WR6030A）で A/D 変換され, 記録される. サンプリング クロックは, $2.0 \mu \mathrm{s}$ である. 取得されたデータは, 8192 点 ごとに 30 回に分けて高速フーリエ変換され, その平均か ら騷音の周波数分布が求められる。

\section{3. 実験結果および考察}

3.1 ノズル形状が騒音低減性能に及ぼす効果 第 6 図 に, 音圧レベル (SPL: Sound pressure level) 周波数分布 の代表例を示す. 空力タブは定常噴射されている. 縦軸は SPL を示す。横軸は実周波数, ならびにランプ下流端での 噴流高さ $(7.2 \mathrm{~mm})$ と流速 $(340 \mathrm{~m} / \mathrm{s})$ に基づくストロー ハル数5) を示す．黑線が空力タブなし (W/O AT), 扊線 が円形ノズル（Round AT- $0.8 \mathrm{~mm}-0.60 \mathrm{MPa}$ ) の結果で ある。

空力タブの使用・不使用によらず，周波数分布はブロー ドバンドのピークを持つ，空力タブを用いることで，幅広 い周波数域において $\mathrm{SPL}$ が $3 \mathrm{~dB}$ 程度低減することが分か る. OASPL も約 $3 \mathrm{~dB}$ 低減する. 空力タブにより主噴流 の二次元性が破壊され, 組織的渦形成がある程度抑制され た2 と) と考えられる。これに伴い, 放出される騒音も低減 すると考えられる.なお，ランプ下流端・カウル下流端の トレーリングエッジ形状が，前報5) で使用した供試ノズル と異なるため, SPLの絶対值は若干（1 dB 程度）低下して いる。ただ，空力タブ使用による SPL 低減量はほぼ同じ結 果であることを追記しておく.

第 7 図に, 空力タブ全圧と OASPL 変化量の関係を示す. 空力タブは定常噴射されている。縦軸は OASPL 変化量を, 横軸は空力夕ブ全圧を示す. OASPLが減少した場合, その

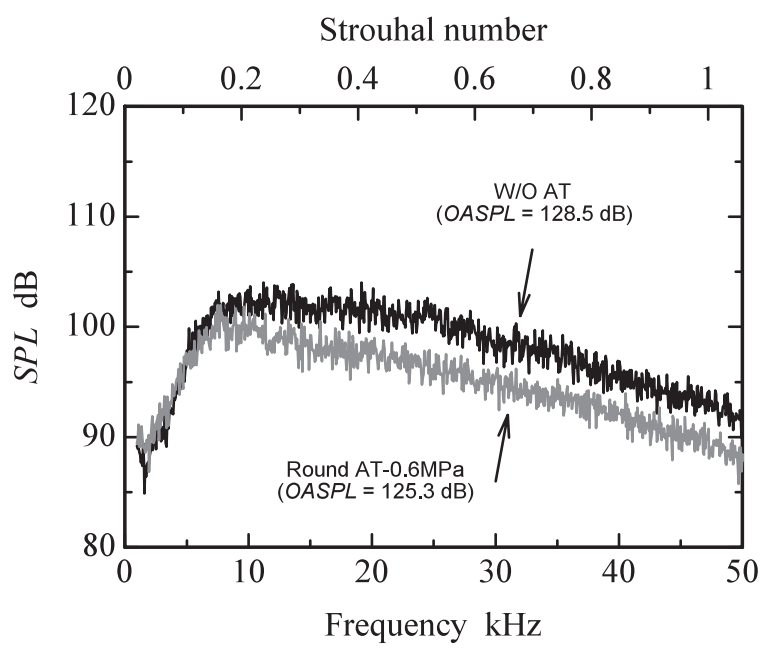

第 6 図 SPL 周波数分布 (定常噴射, Round AT, $x=130 \mathrm{~mm}, y=$ $120 \mathrm{~mm}$ ) 
変化量は負号で表記される．4種類の円形ノズル（Round $\mathrm{AT}$ ), ならびに 2 種類のくさび形ノズル (Wedge AT) の 結果が示されている.

第 6 図より，円形ノズル，〈さび形ノズルの違いによら ず, 空力タブ全圧の増大とともに OASPL は減少していく ことが分かる。また，ノズルが大きいほうが OASPL 低減 の度合いが大きい. ノズル直径 $d=1.0 \mathrm{~mm}$ の円形ノズ ル（Round AT）を用いた場合, OASPL を最大で $4 \mathrm{~dB}$ 程 度減少することができる。また，くさび形ノズル（Wedge $\mathrm{AT}$ をを用いた場合には，OASPL を最大で $3 \mathrm{~dB}$ 程度減少 することができる.

第 8 図に, 空力タブ質量流量と OASPL 変化量の関係を 示す. 空力タブは定常噴射されている. 縦軸は OASPL 変 化量を, 横軸は主噴流質量流量に対する空力夕ブ質量流量 の割合を示す. OASPL が減少した場合, その変化量は負 号で表記される。質量流量は, 空力タブノズル出口にて流 れが閉塞すると仮定し，ノズル出口面積，および空力タブ 全圧から見積もった． 4 種類の円形ノズル（Round AT), ならびに 2 種類のくさび形ノズル（Wedge AT) の結果が 示されている.

第 8 図より，横軸を空力タブ質量流量とすることで，円

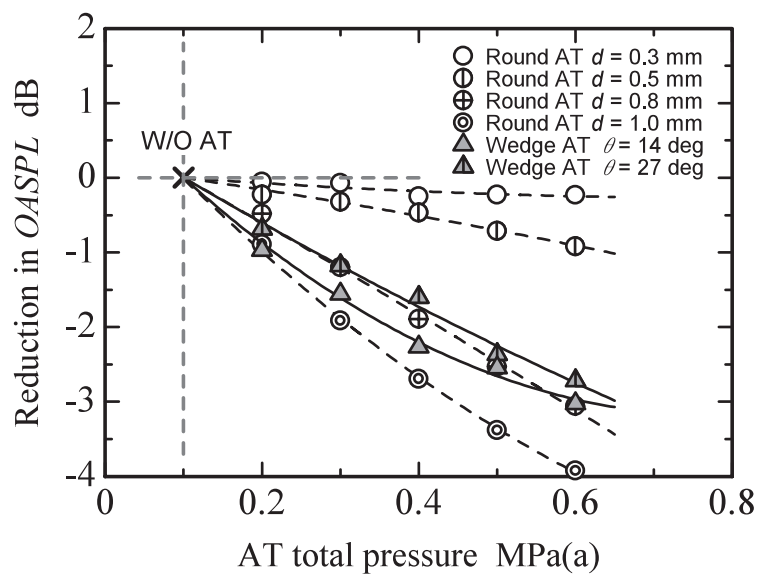

第 7 図 空力タブ全圧と OASPL 変化量の関係（定常噴射， $x=$ $130 \mathrm{~mm}, y=120 \mathrm{~mm}$ )

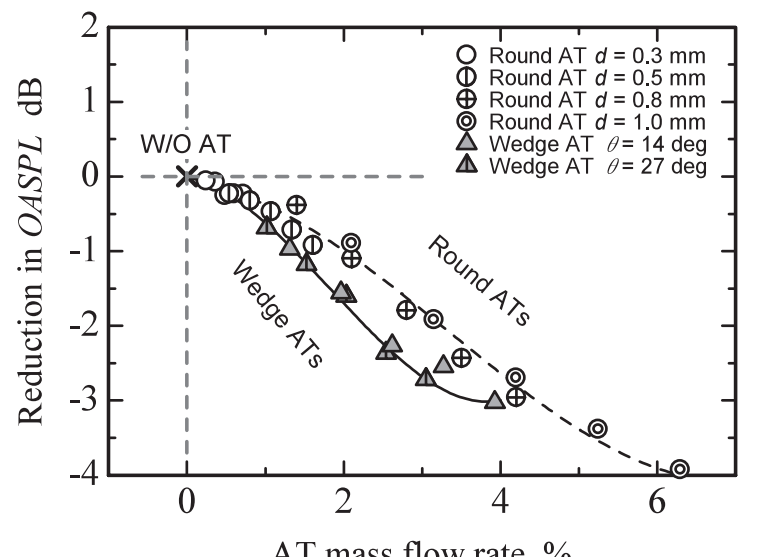

第 8 図 空力タブ質量流量と OASPL 変化量の関係 (定常噴射, $x=$ $130 \mathrm{~mm}, \quad y=120 \mathrm{~mm}$ )
形ノズル (Round AT) とくさび形ノズル (Wedge AT) の結果が，それぞれ 1 つの曲線に集まることが分かる。空 力夕ブの騒音低減効果において, 質量流量は支配的なパラ メータであることが分かる。また，〈さび型ノズルを用い た場合，より少ない質量流量で円形ノズルと同等の騒音低 減効果が得られることが分かる。

ノズルスロートを通過した主噴流は超音速まで加速され ており，大きな運動量を有する。〈くざ形ノズルを用いる ことで噴射気体の貫通高さが増大し6)，騒音低減効果が大 きく現れたと推察される，ただし本研究の範囲では，くさ び全角 $\theta$ の違いによる効果はほとんど現れていない. 今後, くさび全角 $\theta$ の効果について詳細な検討が必要であると考 えている。第 8 図より, 例えば OASPLを $2.3 \mathrm{~dB}$ 低減する 場合, 円形ノズルをくさび形ノズルに変更することで，空 力タブ質量流量を約 $29 \%$ 低減できることが示された.

3.2 間欠噴射が騷音低減性能に及ぼす効果 第 9 図に, 空力タブ質量流量と OASPL 変化量の関係を示す. 空力夕 ブは間欠噴射されている。ノズル直径 $d=0.8 \mathrm{~mm}$ の円形 ノズル（Round AT）の結果を示す. 縦軸は OASPL 変化 量を, 横軸は主噴流質量流量に対する空力タブ質量流量の 割合を示す。なお間欠噴射の場合, 空力夕ブ質量流量は時 間とともに変動する。このため空力タブ質量流量は, 時間 平均值で表記される。OASPL が減少した場合，その変化 量は負号で表記される. 質量流量は, 空力タブノズル出口 にて流れが閉塞すると仮定し，ノズル出口面積, 空力タブ 全圧 $(0.6 \mathrm{MPa}(\mathrm{a})$ で固定 $)$, および噴射デューティー比か ら見積もった. 同一ノズルの場合, 質量流量はデューティー 比 $D R$ のみで決まり， $D R=1.0$ が定常噴射に対応する. なお第 9 図には，定常噴射の結果を合わせて示す。この場 合，質量流量は空力タブ全圧に応じて変化する。

第 9 図より，定常噴射と比較し間欠噴射の方がより小さ い質量流量で同等の OASPL 低減効果が現れることが分か る.また，噴射周波数 $f$ を $10 \mathrm{~Hz}, 50 \mathrm{~Hz}$ と増大していく と, 必要とされる質量流量は減少していく，たたし，噴射 周波数 $f>50 \mathrm{~Hz}$ の条件では質量流量はほとんど変わら ず，騒音低減効果は飽和するようである.

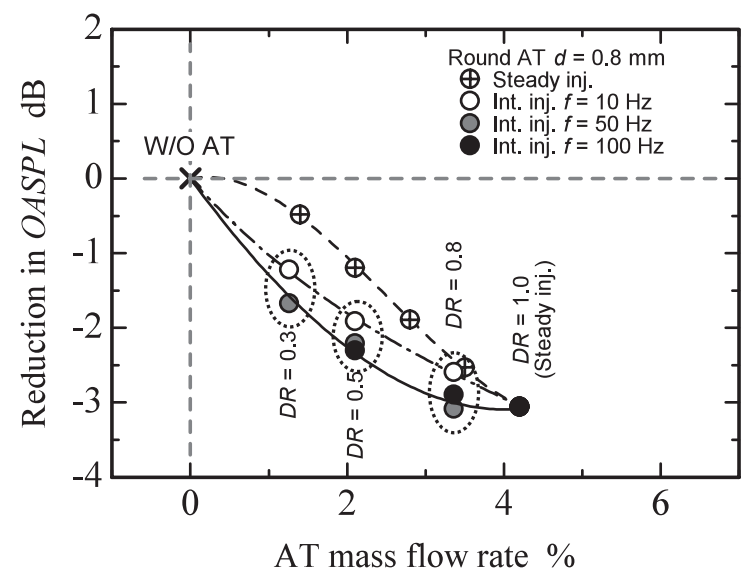

第 9 図 空力タブ質量流量と OASPL 変化量の関係 (間欠噴射, Round AT, $x=130 \mathrm{~mm}, y=120 \mathrm{~mm}$ ) 


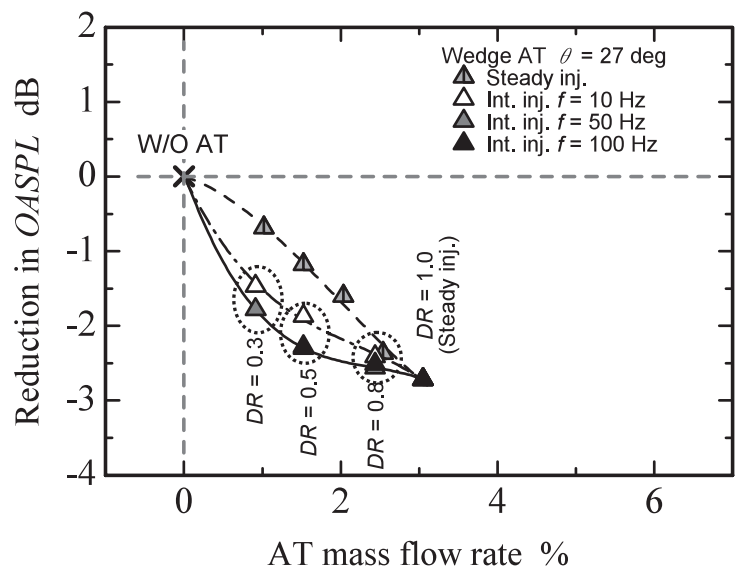

第 10 図 空力タブ質量流量と OASPL 変化量の関係（間欠噴射, Wedge AT, $x=130 \mathrm{~mm}, y=120 \mathrm{~mm}$ )

空力タブの噴射により，主噴流の流れ場は二次元性を失 い変形する5)。一度流れ場が変形すると, その後短時間で あれば空力タブの噴射を休止しても影響が残るものと推察 される. 空力夕ブ噴射周波数 $f$ は最低でも $50 \mathrm{~Hz}$ 以上で ある必要があることから, 流れの変形の影響が保存される 特性時間は $20 \mathrm{~ms}$ 程度と考えられる。第 9 図より，例えば OASPL を $2.3 \mathrm{~dB}$ 低減する場合, 定常噴射を間欠噴射とす ることで, 空力夕ブ質量流量を約 $37 \%$ 低減できることが示 された。

第 10 図に，空力タブ質量流量と OASPL 変化量の関係 を示す. 空力タブは間欠噴射されている. 全角 $\theta=27 \mathrm{deg}$ のくさび形ノズル (Wedge AT) の結果を示す. 図の体裁 は，第 8 図と同様である。縦軸は OASPL 変化量を，横軸 は主噴流質量流量に対する空力タブ質量流量の割合を示す. OASPL が減少した場合，その変化量は負号で表記される。 定常噴射の結果を合わせて示す.

第 10 図より, 円形ノズルの結果と同様に, 定常噴射と比 較し間欠噴射の方がより小さい質量流量で同等の OASPL 低減効果が現れることが分かる. また, 噴射周波数 $f$ を $10 \mathrm{~Hz}, 50 \mathrm{~Hz}$ と増大していくと, 必要とされる質量流量は 減少していく．ただし，噴射周波数 $f>50 \mathrm{~Hz}$ の条件では 質量流量はほとんど変わらず，騒音低減効果は飽和するよ うである。第 10 図より，例えば OASPL を $2.3 \mathrm{~dB}$ 低減す る場合, 定常噴射を間欠噴射とすることで, 空力夕ブ質量 流量を約 $40 \%$ 低減できることが示された。

以上の議論から，従来の円形ノズルからの定常噴射5) と 比較して，(i)くさび形ノズル適用により, 空力タブに必要 とされる質量流量を約 $29 \%$ 低減可能であること，ならびに (ii) 間欠噴射適用により, 空力タブに必要とされる質量流量 を $40 \%$ 程度低減可能であることが示された。 くさび形ノズ ルと間欠噴射を組み合わせた結果では，従来の円形ノズル からの定常噴射と比較し, 同程度の騒音低減性能 $\mathrm{OASPL}$ を $2.3 \mathrm{~dB}$ 低減）を達成するのに必要な質量流量は，3.6\%か ら $1.5 \%$ まで減少する。空力夕ブ質量流量を約 $57 \%$ 低減す ることが可能であり, その実用化を考える上で極めて重要 な結果であると考えている。

\section{4. 結言}

空力タブを用い，矩形プラグノズルからの排気騷音低減 を試みた。矩形プラグノズルから, 実機エンジン離陸時条 件の主噴流を噴出する。空力夕ブのノズル形状を円形から くさび形に，また定常噴射を間欠噴射に変更し，それに伴う 排気騒音の变化を計測した。 その結果, 以下の知見を得た.

1）空力タブのノズルに，直径の異なる円形ノズルを用い た結果，OASPL 減少量はノズル直径によらず質量流量の みで決まることが示された。

2）空力タブのノズルに，全角の異なるくさび形ノズルを 用いた結果，OASPL 減少量はくさび全角によらず質量流 量のみで決まることが示された。また円形ノズルの結果と 比較し, 空力タブ質量流量を $29 \%$ 低減可能であることが示 された。

3）空力タブからの気体噴射を，定常噴射から間欠噴射に 変更した結果, 円型ノズルの場合には, 空力タブ質量流量 を約 $37 \%$ 低減可能であることが示された。 また，くさび形 ノズルの場合には，空力タブ質量流量を約 $40 \%$ 低減可能で あることが示された。

4）〈さび形ノズルと間欠噴射を組み合わせた結果では, 従来の円形ノズルからの定常噴射と比較し，同程度の騒音 低減性能（OASPL を $2.3 \mathrm{~dB}$ 低減）を達成するのに必要な 空力夕ブ質量流量を, 約 $57 \%$ と大幅に減少できることが示 された。

本研究は, 宇宙航空研究開発機構 (JAXA) から群馬大 学への委託研究として実施された. 本研究の一部は, 文部科 学省科学研究費補助金（課題番号：15760595, 17760634) の助成のもと実施された. 本研究の実施に当り群馬大学学 部生（当時）長山 司君, 群馬大学大学院生（当時）曽根 祐輔君, 群馬大学工学部 中村壽雄技術専門職員の援助を頂 いた。ここに記して謝意を表する。

\section{参 考 文 献}

1) Taguchi, H., Sato, T., Kobayashi, H., Kojima, T., Okai, K. and Fujita, K.: Design Study on a Small Pre-Cooled Turbojet Engine for Flight Experiments, AIAA Paper 2005-3419, 2005 .

2) 荒木幹也, 桑原孝輔, 新井正明, 石間経章, 志賀聖一, 小保方富 夫：ノズル壁面からの気体噴射による超音速噴流の騒音低減，日 本機械学会論文集 B 編, 71 (2005), pp. 1798-1805.

3) Araki, M., Kuwabara, K., Shiga, S. and Obokata, T.: Effects of Aerodynamic Tabs on Screech Reduction of a Supersonic Jet, AIAA J., 44 (2006), pp. 408-411.

4）荒木幹也, 桑原孝輔, 曾根祐輔, 志賀聖一, 小保方富夫：超音速 噴流における空力タブの騒音低減性能, 日本機械学会論文集 B 編， 73 (2007), pp. 567-574.

5）荒木幹也, 佐野貴透, 小島孝之, 田口秀之, 志賀聖一, 小保方富 夫 : 矩形プラグノズルからの排気騒音に及ぼす空力夕ブの効果, 日本航空宇宙学会論文集，56 (2008), pp. 149-156.

6) Barber, M. J., Schetz, J. A. and Roe, L. A.: Normal, Sonic Helium Injection through a Wedge-Shaped Orifice into Supersonic Flow, J. Propul. Power, 13 (1997), pp. 257-263.

7) 荒木幹也，藤原康裕，志賀聖一，中村壽雄，小保方富夫：気体燃 料噴射弁の噴射率計測精度向上，日本機械学会論文集 B 編， 74 (2008), pp. $715-723$. 